\begin{tabular}{|c|c|c|c|}
\hline & $\begin{array}{r}\text { Anna } \\
\text { http://wv }\end{array}$ & $\begin{array}{l}\text { Journal } \\
\text { sindex.php }\end{array}$ & \multirow{2}{*}{ 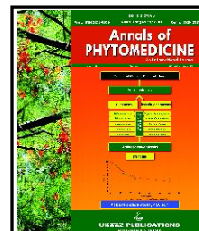 } \\
\hline & Print ISSN : 2278-9839 & Online ISSN : 2393-9885 & \\
\hline
\end{tabular}

Original article

\title{
Pharmacokinetic profile of rutin after intramuscular administration in rats favours its in vivo anti-inflammatory activity in carrageenan- induced rodent model of inflammation
}

\author{
Falguni D. Modi», Shailesh K. Bhavsar*, Jatin H. Patel, Rasesh D. Varia, Lalit C. Modi**, Megha Modi \\ and Nitin Kale \\ Department of Veterinary Pharmacology and Toxicology, College of Veterinary Science and A.H., Navsari Agricultural \\ University, Navsari-396450, Gujarat, India \\ *Department of Veterinary Pharmacology and Toxicology, College of Veterinary Science and A.H., Anand Agricultural \\ University, Anand-388110, Gujarat, India \\ **Department of Veterinary Gynecology, College of Veterinary Science and A.H., Navsari Agricultural University, \\ Navsari-396450, Gujarat, India
}

Received February 10, 2019: Revised March 27, 2019: Accepted March 29, 2019: Published online June 30, 2019

\begin{abstract}
The study was planned to evaluate pharmacokinetic profile and in vivo anti-inflammatory property of rutin following intramuscular administration $(100 \mathrm{mg} / \mathrm{kg}$, intramuscular) in rats. Carrageenan-induced paw edema assay was carried out separately to study in vivo anti-inflammatory property of rutin. The plasma rutin concentration was assayed using High Performance Liquid Chromatography (HPLC). The pharmacokinetic parameters like the maximum plasma drug concentration $\left(\mathrm{C}_{\max }\right)$, time for maximal concentration $\left(\mathrm{T}_{\max }\right)$, elimination half-life $\left(\mathrm{t}_{1 / 2 \beta}\right)$, apparent volume of distribution $\left(\mathrm{Vd}_{\text {(area) }}\right)$, total body clearance $\left(\mathrm{Cl}_{(\mathrm{B})}\right)$ and mean residence time (MRT) were $21.11 \pm$ $0.46 \mu \mathrm{g} / \mathrm{ml}, 1.83 \pm 0.17 \mathrm{~h}, 9.11 \pm 1.50 \mathrm{~h}, 16.34 \pm 2.32 \mathrm{l} / \mathrm{kg}, 1.27 \pm 0.04 \mathrm{l} / \mathrm{h} / \mathrm{kg}$ and $4.79 \pm 0.55 \mathrm{~h}$, respectively. The drug concentration of $0.21 \pm 0.02 \mu \mathrm{g} / \mathrm{ml}$ in plasma was detected at $24 \mathrm{~h}$. In carrageenan-induced paw edema assay, rutin $(100 \mathrm{mg} / \mathrm{kg})$ significantly decreased edema volume from 1 to $6 \mathrm{~h}$ in comparison to carrageenan group and vehicle group. Per cent inhibition of inflammation after $6 \mathrm{~h}$ of rutin administration was $29.94 \pm 1.49$. Intramuscular administration of rutin produced satisfactory pharmacokinetic profile with promising in vivo anti-inflammatory activity in rats.
\end{abstract}

Keywords: Pharmacokinetic profile, anti-inflammatory activity, rutin, intramuscular, rat

\section{Introduction}

Inflammation is the complex biological response of vascular tissues to harmful stimuli such as pathogens, damaged cells or irritants. Inflammation is a protective attempt by the organism to remove the injurious stimuli as well as to initiate the healing process for the tissue (Jayakumari et al., 2012). Currently available analgesic and anti-inflammatory agents include corticosteroids and nonsteroidal anti-inflammatory drugs (Khan et al., 2015). Long term use of these drugs may cause side effects pertaining to liver and kidney (Bhadarka et al., 2018). Thus, the discovery of new antiinflammatory compounds is still on great demand by scientists in academia and industry. Drugs of herbal origin provide a rational means for the treatment of several ailments in human and animals (Nayanabhirama, 2016). It is important to mention that traditional medicinal systems are at a transitional stage in the development of

Author for correspondence: Dr. Falguni D. Modi Assistant Professor, Department of Veterinary Pharmacology and Toxicology, College Veterinary Science and A.H., Navsari Agricultural University, Navsari-396450, Gujarat, India

E-mail: fdmodi@nau.in

Tel.: +91-7600049181

Copyright $\odot 2019$ Ukaaz Publications. All rights reserved.

Email: ukaaz@yahoo.com; Website: www.ukaazpublications.com modern medicines in developing countries (Thakur et al., 2018). Active principles from many herbs have shown promising antiinflammatory activity. Amongst them, flavonoids have been reported to show promising anti-inflammatory properties, either in vitro or in vivo (Vasudevan et al., 2007).

Rutin (3, 3', 4', 5, 7-pentahydroxyflavone-3-rhamnoglucoside) is a flavonol, abundantly found in plants, such as passion flower, buckwheat, tea, and apple, and also called as quercetin-3-rutinoside and sophorin (Kreft et al.,1997). Rutin has been described as cellprotecting agents because of their antioxidant and antinociceptive and it was proposed as preventive effect of rutin on oxaliplatininduced painful peripheral neuropathy based on their antioxidant properties (Azevedo et al., 2013). Rutin as parent compound was not detected in plasma and absolute systemic bioavailability is negligible, following oral administration due to first pass metabolism (Day et al., 1998; Jaganath et al., 2006). Thus, looking to need of a study related to pharmacokinetic profile of rutin after intramuscular administration along with in vivo evaluation of its anti-inflammatory activity in animals, present study was planned to generate data related to disposition and in vivo anti-inflammatory efficacy of rutin in rodent model which would be useful for future research on therapeutic application of rutin. 


\section{Materials and Methods}

\subsection{Experimental animals}

The experiment was conducted in two sets on 54 male albino wistar rats weighing between 300 to $400 \mathrm{~g}$. Rats were kept under constant observation for two weeks before the commencement of the experiment and subjected to clinical examination to exclude possibility of any disease. The animals were randomly divided into groups and kept in polypropylene cages. Standard ration and water was provided ad libitum. The study protocol was approved by Institutional Animal Ethics Committee (IAEC), College of Veterinary Science and A. H., NAU, Navsari. (No. NAU/NVC/IAEC/12/2017, dated:11/11/2017).

\subsection{Drugs and chemicals}

Rutin hydrate, meloxicam sodium $(>98 \%)$ and lambda $(\lambda)$ carrageenan were purchased from Sigma-Aldrich, USA. Dimethyl sulfoxide (DMSO), PEG200, methanol, acetonitrile, glacial acetic acid and ortho-phosphoric acid were purchased from Merck Specialties PVT. LTD., Mumbai. Ethanol was procured from store department of College of Veterinary Science and A.H., N.A.U., Navsari and used after triple distillation.

\subsection{Experimental design for pharmacokinetic study}

Six sets were made using 30 male rats. Each group comprise of five animals. A single dose of rutin (dissolved in vehicle containing DMSO, PEG200 and ethanol in 4:3:3 ratio) was given by intramuscular route to all animals at dose rate of $100 \mathrm{mg} / \mathrm{kg}$ of body weight. Blood samples $(250 \mu \mathrm{l})$ were collected from treated rats in $\mathrm{K}_{3}$ EDTA vials, at different time intervals, i.e., 0 (before drug administration), 0.08 (5 min), 0.25 (15 min), 0.5 (30 $\mathrm{min}), 1,2,4,6,8,12,18,24$ and 36 $\mathrm{h}$ from retro orbital plexus under light anesthesia. Multiple numbers of rat were used for serial collection of blood at alternating time point. Blood samples were centrifuged at $5000 \mathrm{rpm}$ for $10 \mathrm{~min}$ to separate plasma. Plasma samples were transferred to cryo-vials and then stored at $-20^{\circ} \mathrm{C}$. The plasma samples were used to know the concentration of rutin by using HPLC and data of plasma rutin concentrations were used to calculate pharmacokinetic profile as described below.

\subsection{HPLC analysis of rutin from plasma samples}

For the precipitation of the plasma protein, acetonitrile and glacial acetic acid mixture (9:1 ratio) was added in plasma as 1:1 ratio and was mixed in a clean microcentrifuge tube on a vortex mixer for $1 \mathrm{~min}$. It was followed by centrifugation for $15 \mathrm{~min}$ at $8000 \mathrm{rpm}$. The clean supernatant was transferred into inserts of automatic sampler vial, from which $20 \mu \mathrm{l}$ of supernatant was injected into high performance liquid chromatography (HPLC) system.

Plasma samples were analyzed within $24 \mathrm{~h}$ to quantify rutin using HPLC system by using procedure as described by Yang et al. (2013) with minor modifications. In brief, the HPLC apparatus of Shimadzu (Japan) comprised of binary gradient delivery pump (model LC 20AP), diode array detector (model SPD M20A), auto sampler (model SIL 20A) and reverse phase C18 column $(250 \times 4.6 \mathrm{~mm}$ ID). The mobile phase was mixture of $1 \%$ glacial acetic acid, methanol and acetonitrile $(50: 45: 5 \mathrm{v} / \mathrm{v})$ with $\mathrm{pH}$ of 3.07. Mobile phase was filtered by $0.2 \mu$ size filter (Axiva, N66) and degassed by ultrasonication. The mobile phase was pumped into column at a flow rate of $1.0 \mathrm{ml} / \mathrm{min}$ at ambient temperature and a detection wavelength of $257 \mathrm{~nm}$. The total runtime was $10 \mathrm{~min}$ for each injection.

For plasma validation of HPLC method, initial stock solution of rutin was prepared by dissolving $2 \mathrm{mg}$ rutin in $2 \mathrm{ml}$ DMSO, PEG200 and ethanol $(4: 3: 3)$. Final standards were prepared in drug-free plasma of rat. Quantification of rutin in plasma samples was done by reference to the resultant standard curve (Figure 1). The calibration curves showed good linearity over the concentration ranges 0.09 to $25 \mu \mathrm{g} / \mathrm{ml}$ with a mean correlation coefficient $\left(\mathrm{R}^{2}\right)$ was 0.99. Representative chromatograms of blank plasma of rat, rutin standard (Retention time: $5.4 \mathrm{~min}$ ) in plasma $(3.125 \mu \mathrm{g} / \mathrm{ml})$ and $2 \mathrm{~h}$ post intramuscular administration of rutin (Retention time: $5.4 \mathrm{~min}$ ) in rat are depicted in Figure 2. The precision and accuracy of the assay were assessed using samples at concentration of 12.50 , $1.56,0.39$ and $0.09 \mu \mathrm{g} / \mathrm{ml}$. At all concentrations, the C.V. was less than $7.89 \%$. The lower limit of detection and limits of quantification of the drug was $0.02 \mu \mathrm{g} / \mathrm{ml}$ and $0.09 \mu \mathrm{g} / \mathrm{ml}$, respectively.

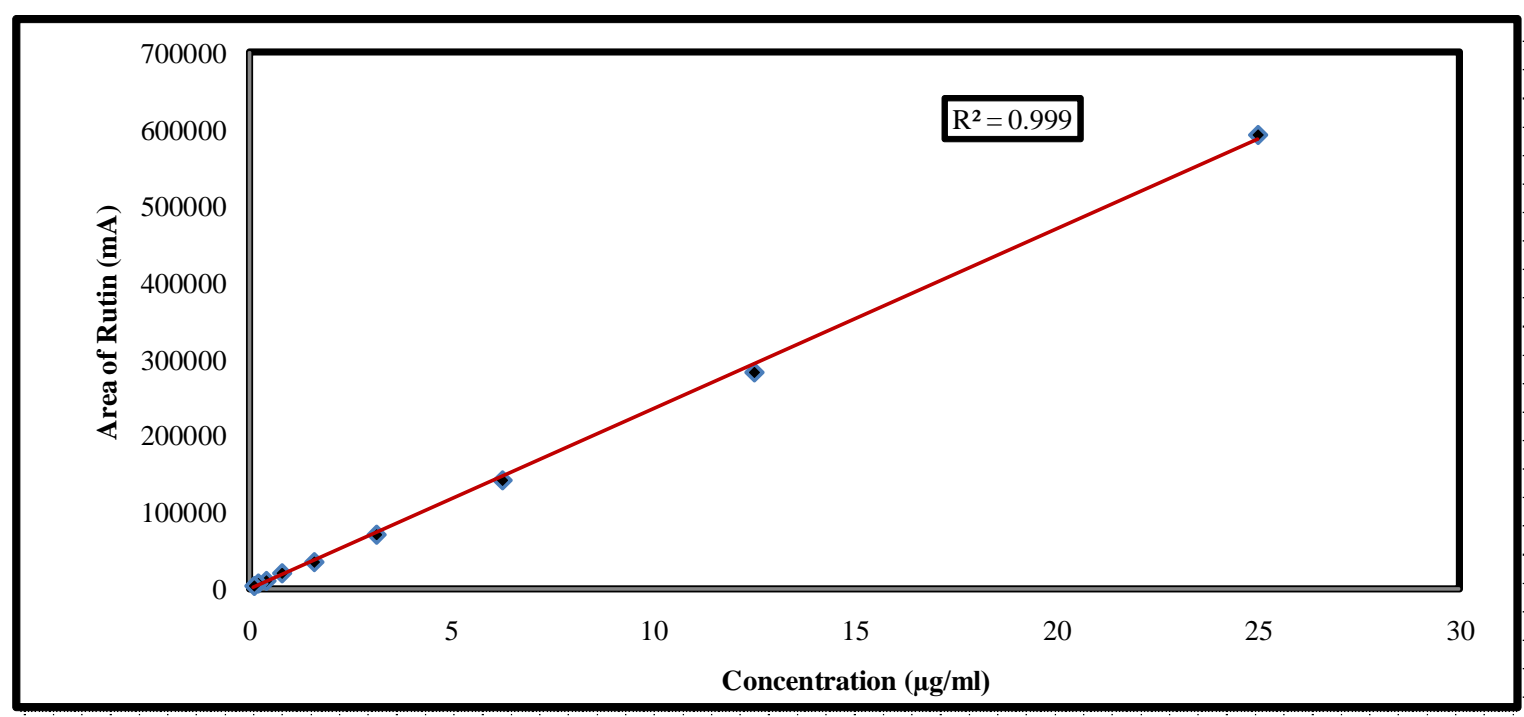

Figure 1: Standard curve of rutin in drug-free plasma of rats. 

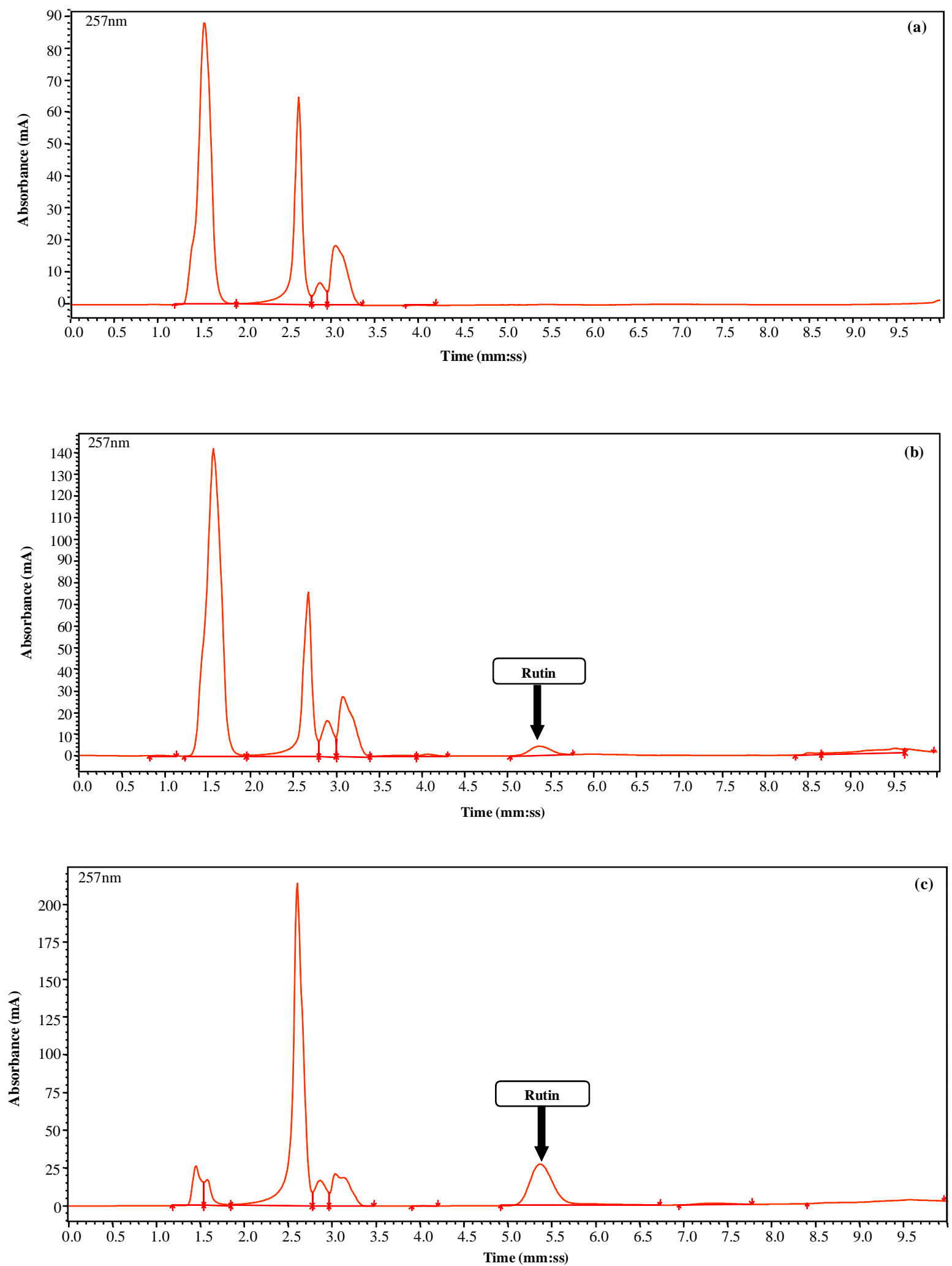

Figure 2: Representative chromatograms of (a) blank plasma of rat, (b) rutin standard (RT: $5.4 \mathrm{~min}$ ) in plasma $(3.125 \mu \mathrm{g} / \mathrm{ml}$ ), (c) $2 \mathrm{~h}$ post intramuscular administration of rutin (RT: $5.4 \mathrm{~min})$ in rat. 


\subsection{Calculation of pharmacokinetic parameters}

Pharmacokinetic parameters were calculated as per standard methods (Baggot, 1977; Gibaldi and Perrier, 1982). Absorption rate constant $(\alpha)$ and elimination rate constant $(\beta)$ were calculated by least square regression analysis method. Absorption half-life $\left(\mathrm{t}_{1 / 2 \alpha}\right)$ and elimination half-life $\left(\mathrm{t}_{1 / \beta}\right)$ were calculated from $0.693 / \alpha$ and $0.693 / \beta$, respectively. Maximum drug concentration in plasma $(\mathrm{Cmax})$ and time of maximum observed concentration in plasma (Tmax) were obtained from actual plasma concentrations of each rat. Area under curve $\left(\mathrm{AUC}_{(0-\infty)}\right)$ and area under the first moment of curve (AUMC) were calculated by linear trapezoidal rule. Apparent volume of distribution $\left(\mathrm{Vd}_{\text {(area) }} / \mathrm{F}\right)$ was calculated from $($ Dose $\times \mathrm{F}) /(\beta$ $\times$ AUC). The value of total body clearance $\left(\mathrm{Cl}_{(\mathrm{B})}\right)$ was obtained using formula $\beta \times \mathrm{Vd}_{\text {(area) }}$. Mean residence time (MRT) was obtained by dividing the value of AUMC by AUC.

\subsection{Anti-inflammatory activity of rutin in carrageenan- induced paw edema}

The carrageenan-induced paw edema test was used with slight modification as described previously (Suebsasana et al., 2009). Experimental animals were divided into four groups $(n=6)$. All the animals were treated with $100 \mu \mathrm{l}$ of $1 \%$ lambda carrageenan solution in $0.9 \%$ normal saline subcutaneously into subplantar region of right hind paw. Half an hour before the carrageenan challenge, vehicle test and positive control drugs were injected via intramuscular route. Group I animals were treated intramuscularly with $200 \mu \mathrm{l}$ of DMSO: PEG200 (1:1) (vehicle control). Group II animals acted as carrageenan control, Group III animals were treated with meloxicam
( $5 \mathrm{mg} / \mathrm{kg}$, Intramuscular) and Group IV animals were treated with rutin (100 mg/kg Intramuscular). Make a mark on the left hind paw and volume of the edematous paw was measured using a plethysmometer after carrageenan treatment at $0,1,2,4,5$ and $6 \mathrm{~h}$. The anti-inflammatory activities were calculated as the degree of paw edema (e) using the formula: $\mathrm{e}=\left[\left(\mathrm{E}_{0}-\mathrm{E}_{\mathrm{t}}\right) / \mathrm{E}_{0}\right] \times 100\left(\right.$ where, $\mathrm{E}_{0}=$ Paw volume at the baseline, $\mathrm{E}_{\mathrm{t}}=$ Paw volume at a particular reading time of the right hind paw). The results obtained for the meloxicam and rutin treated groups were compared with the control for per cent inhibition of edema.

\subsection{Statistical analysis}

All data obtained for pharmacokinetic parameters and antiinflammatory activity of rutin was presented as Mean \pm S.E. The data for percent inhibition of inflammation were suitably tabulated and analyzed by ' $t$ ' test and carrageenan-induced rat paw edema volume $(\mathrm{ml})$ for different treatment groups, were compared by using Duncan's new multiple range test (DNMRT). The levels of significance to observe difference were 0.05 and 0.01 . The $p$ values $<0.05$ or $<0.01$ were considered as statistically significant or highly significant, respectively.

\section{Results}

\subsection{Pharmacokinetic profile of rutin}

Rutin levels of plasma as a function of time schedule after its single intramuscular administration in rats is presented in Table 1, while semilogarithmic plots of the same have been presented in Figure 3. Pharmacokinetic parameters of rutin following single dose intramuscular administration of rutin in rats are shown in Table 2 .

Table 1: Plasma concentration $(\mu \mathrm{g} / \mathrm{ml})$ of rutin $(100 \mathrm{mg} / \mathrm{kg})$ following intramuscular administration in rats $(\mathrm{n}=6)$

\begin{tabular}{|c|c|c|c|c|c|c|c|}
\hline \multirow{3}{*}{$\begin{array}{l}\text { Time after drug } \\
\text { administration }(h)\end{array}$} & \multicolumn{6}{|c|}{ Plasma concentration $(\mu \mathrm{g} / \mathrm{ml})$} & \multirow[t]{3}{*}{ Mean \pm S.E } \\
\hline & \multicolumn{6}{|c|}{ Rat number } & \\
\hline & $\mathbf{R} 1$ & $\mathbf{R} 2$ & $\mathbf{R 3}$ & R4 & $\mathbf{R 5}$ & R6 & \\
\hline 0.08 & 9.14 & 9.65 & 6.31 & 8.35 & 9.43 & 9.07 & $8.66 \pm 0.50$ \\
\hline 0.25 & 14.89 & 11.20 & 11.76 & 12.35 & 13.04 & 11.41 & $12.44 \pm 0.56$ \\
\hline 0.5 & 14.62 & 11.96 & 16.22 & 13.37 & 14.04 & 9.10 & $13.22 \pm 1.00$ \\
\hline 1 & 22.69 & 8.96 & 11.62 & 10.71 & 12.43 & 17.42 & $13.97 \pm 2.10$ \\
\hline 2 & 20.74 & 22.91 & 19.55 & 20.75 & 21.78 & 20.92 & $21.11 \pm 0.46$ \\
\hline 4 & 7.22 & 6.58 & 5.65 & 5.44 & 5.96 & 6.47 & $6.22 \pm 0.27$ \\
\hline 6 & 2.44 & 2.51 & 1.91 & 2.35 & 1.80 & 2.25 & $2.21 \pm 0.12$ \\
\hline 8 & 1.52 & 1.32 & 1.00 & 0.99 & 0.86 & 1.36 & $1.17 \pm 0.11$ \\
\hline 12 & 0.66 & 0.58 & 0.44 & 0.48 & 0.66 & 0.41 & $0.54 \pm 0.05$ \\
\hline 18 & 0.31 & 0.40 & 0.35 & 0.37 & 0.26 & 0.32 & $0.34 \pm 0.02$ \\
\hline 24 & 0.20 & 0.31 & 0.18 & 0.20 & 0.14 & 0.21 & $0.21 \pm 0.02$ \\
\hline
\end{tabular}

Following intramuscular administration of rutin, the drug concentration of $8.66 \pm 0.50 \mu \mathrm{g} / \mathrm{ml}$ was observed at $0.08 \mathrm{~h}$. The mean peak plasma drug concentration of $21.11 \pm 0.46 \mu \mathrm{g} / \mathrm{ml}$ was achieved at $2 \mathrm{~h}$ which declined rapidly to $6.22 \pm 0.27 \mu \mathrm{g} / \mathrm{ml}$ at $4 \mathrm{~h}$. The drug concentration of $0.21 \pm 0.02 \mu \mathrm{g} / \mathrm{ml}$ in plasma was detected at $24 \mathrm{~h}$ and beyond, then the drug was not detected in plasma. Following intramuscular administration of the rutin, the distribution half-life $\left(\mathrm{t}_{1 / 2 \alpha}\right)$ and elimination half-life $\left(\mathrm{t}_{1 / 2 \beta}\right)$ were $1.58 \pm 0.11 \mathrm{~h}$ and $9.11 \pm 1.50 \mathrm{~h}$, respectively. The mean apparent volume of distribution $\left(\mathrm{Vd}_{(\text {area })}\right)$, total body clearance $\left(\mathrm{Cl}_{(\mathrm{B})}\right)$ and mean residence time (MRT) were $16.34 \pm 2.32 \mathrm{1} / \mathrm{kg}, 1.27 \pm 0.04 \mathrm{l} / \mathrm{h} / \mathrm{kg}$ and $4.79 \pm$ $0.55 \mathrm{~h}$, respectively.

\subsection{Anti-inflammatory activity of rutin}

The mean anti-inflammatory activity of meloxicam and rutin was assessed using the carrageenan-induced paw edema model in rats. Change in the paw edema volume following treatment with vehicle, meloxicam and rutin is shown in Table 3. In carrageenan-induced 
paw edema model, rutin significantly decreased edema volume from 1 to $6 \mathrm{~h}$ in comparison to carrageenan group and vehicle group. Moreover, it was observed that rutin produced comparable effect to that produced by meloxicam up to $2 \mathrm{~h}$ but thereafter effect of meloxicam was significantly higher compared to rutin (Table 4 and Figure 4).

Table 2: Pharmacokinetic parameters of rutin $(100 \mathrm{mg} / \mathrm{kg})$ following intramuscular administration in rats $(n=6)$

\begin{tabular}{|c|c|c|c|c|c|c|c|c|}
\hline \multirow{2}{*}{$\begin{array}{c}\text { PK } \\
\text { Parameter }\end{array}$} & \multicolumn{7}{|c|}{ Rat number } & \multirow[t]{2}{*}{ Mean \pm S.E } \\
\hline & Unit & R1 & $\mathbf{R 2}$ & R3 & R4 & $\mathbf{R 5}$ & R6 & \\
\hline$\alpha$ & $h^{-1}$ & 0.43 & 0.57 & 0.35 & 0.42 & 0.41 & 0.52 & $0.45 \pm 0.03$ \\
\hline$\beta$ & $h^{-1}$ & 0.08 & 0.04 & 0.11 & 0.10 & 0.11 & 0.07 & $0.08 \pm 0.01$ \\
\hline $\mathbf{t}_{1 / 2 \alpha}$ & h & 1.60 & 1.23 & 1.99 & 1.66 & 1.68 & 1.33 & $1.58 \pm 0.11$ \\
\hline $\mathbf{t}_{1 / 2 \beta}$ & h & 9.05 & 16.07 & 6.36 & 6.93 & 6.54 & 9.70 & $9.11 \pm 1.50$ \\
\hline $\mathrm{C}_{\max }$ & $\mu \mathrm{g} / \mathrm{ml}$ & 20.74 & 22.91 & 19.55 & 20.75 & 21.78 & 20.92 & $21.11 \pm 0.46$ \\
\hline $\mathbf{T}_{\max }$ & h & 1.00 & 2.00 & 2.00 & 2.00 & 2.00 & 2.00 & $1.83 \pm 0.17$ \\
\hline $\mathbf{A} \mathbf{U} \mathbf{C}_{(0-\infty)}$ & $\mu \mathrm{g} . \mathrm{h} / \mathrm{ml}$ & 90.03 & 84.69 & 72.01 & 73.59 & 75.81 & 80.38 & $79.42 \pm 2.85$ \\
\hline AUMC & $\mu \mathrm{g} \cdot \mathrm{h}^{2} / \mathrm{ml}$ & 388.13 & 633.05 & 296.19 & 321.34 & 289.02 & 374.21 & $383.66 \pm 52.53$ \\
\hline Vd $d_{\text {(area) }}$ & $1 / \mathrm{kg}$ & 14.51 & 27.37 & 12.74 & 13.58 & 12.45 & 17.41 & $16.34 \pm 2.32$ \\
\hline $\mathrm{Cl}_{(\mathbf{B})}$ & $1 / \mathrm{h} / \mathrm{kg}$ & 1.11 & 1.18 & 1.39 & 1.36 & 1.32 & 1.24 & $1.27 \pm 0.04$ \\
\hline MRT & h & 4.31 & 7.47 & 4.11 & 4.37 & 3.81 & 4.66 & $4.79 \pm 0.55$ \\
\hline
\end{tabular}

$\alpha$ : Absorption rate constant; $\beta$ : Elimination rate constant; $\mathrm{t}_{1 / 2 \alpha}$ : Absorption half-life; $\mathrm{t}_{1 / 2 \beta}$ : Elimination halflife; $\mathrm{C}_{\max }$ : Maximum drug concentration; $\mathrm{T}_{\max }$ : Time of maximum observed concentration in plasma; $\mathrm{AUC}_{(0-\gamma)}$ : Area under curve; AUMC: Area under first moment of curve; $\mathrm{Vd}_{(\text {area })}$ : apparent volume of distribution; $\mathrm{Cl}_{(\mathrm{B})}:$ Total body clearance; MRT: Mean residence time.

Table 3: Effect of rutin on carrageenan-induced rat paw edema volume (ml)

\begin{tabular}{|l|c|c|c|c|c|c|}
\hline Groups & $\mathbf{0 ~ h}$ & $\mathbf{1} \mathbf{h}$ & $\mathbf{2} \mathbf{h}$ & $\mathbf{4} \mathbf{h}$ & $\mathbf{5} \mathbf{h}$ & $\mathbf{6} \mathbf{h}$ \\
\hline Vehicle & $1.84 \pm 0.03^{\mathrm{b}}$ & $2.59 \pm 0.06^{\mathrm{b}}$ & $3.00 \pm 0.04^{\mathrm{c}}$ & $3.48 \pm 0.03^{\mathrm{c}}$ & $4.02 \pm 0.03^{\mathrm{c}}$ & $4.35 \pm 0.08^{\mathrm{c}}$ \\
Carrageenan & $1.94 \pm 0.02^{\mathrm{c}}$ & $2.67 \pm 0.09^{\mathrm{b}}$ & $2.94 \pm 0.02^{\mathrm{c}}$ & $3.51 \pm 0.09^{\mathrm{c}}$ & $4.16 \pm 0.06^{\mathrm{c}}$ & $4.29 \pm 0.05^{\mathrm{c}}$ \\
Meloxicam & $1.73 \pm 0.01^{\mathrm{a}}$ & $2.02 \pm 0.03^{\mathrm{a}}$ & $2.21 \pm 0.03^{\mathrm{a}}$ & $2.29 \pm 0.06^{\mathrm{a}}$ & $2.51 \pm 0.07^{\mathrm{a}}$ & $2.43 \pm 0.07^{\mathrm{a}}$ \\
Rutin & $1.83 \pm 0.03^{\mathrm{b}}$ & $2.10 \pm 0.06^{\mathrm{a}}$ & $2.36 \pm 0.02^{\mathrm{b}}$ & $2.82 \pm 0.09^{\mathrm{b}}$ & $3.19 \pm 0.08^{\mathrm{b}}$ & $3.01 \pm 0.05^{\mathrm{b}}$ \\
\hline
\end{tabular}

Data are expressed as Mean $\pm \mathrm{SE}(\mathrm{n}=6)$; Means bearing different superscripts within a column (between treatment groups) differ significantly $(p<0.01)$.

Table 4: Percent inhibition of inflammation after meloxicam and rutin administration in male albino wistar rats

\begin{tabular}{|l|c|c|c|c|c|}
\hline \multirow{2}{*}{ Groups } & \multicolumn{5}{|c|}{ Percent inhibition of inflammation (Mean \pm SE) } \\
\cline { 2 - 6 } & $\mathbf{1 ~ h}$ & $\mathbf{2}$ h & $\mathbf{4}$ h & $\mathbf{5} \mathbf{~}$ & $\mathbf{6} \mathbf{~ h}$ \\
\hline Meloxicam & $23.99 \pm 3.41$ & $24.70 \pm 0.99$ & $34.70 \pm 1.85$ & $39.46 \pm 1.82$ & $43.52 \pm 1.35$ \\
Rutin & $21.03 \pm 2.46$ & $19.53 \pm 0.65$ & $19.62 \pm 2.72$ & $23.14 \pm 2.31$ & $29.94 \pm 1.49$ \\
T value & 0.705 & $4.367 * *$ & $4.582 * *$ & $5.546 * *$ & $6.755^{* *}$ \\
P value & 0.497 & 0.001 & 0.001 & 0.000 & 0.000 \\
\hline
\end{tabular}

Values are expressed as Mean $\pm \operatorname{SE}(n=6) ; *$ Significant $(p<0.05)$; ** highly significant $(p<0.01)$ difference between two group. 


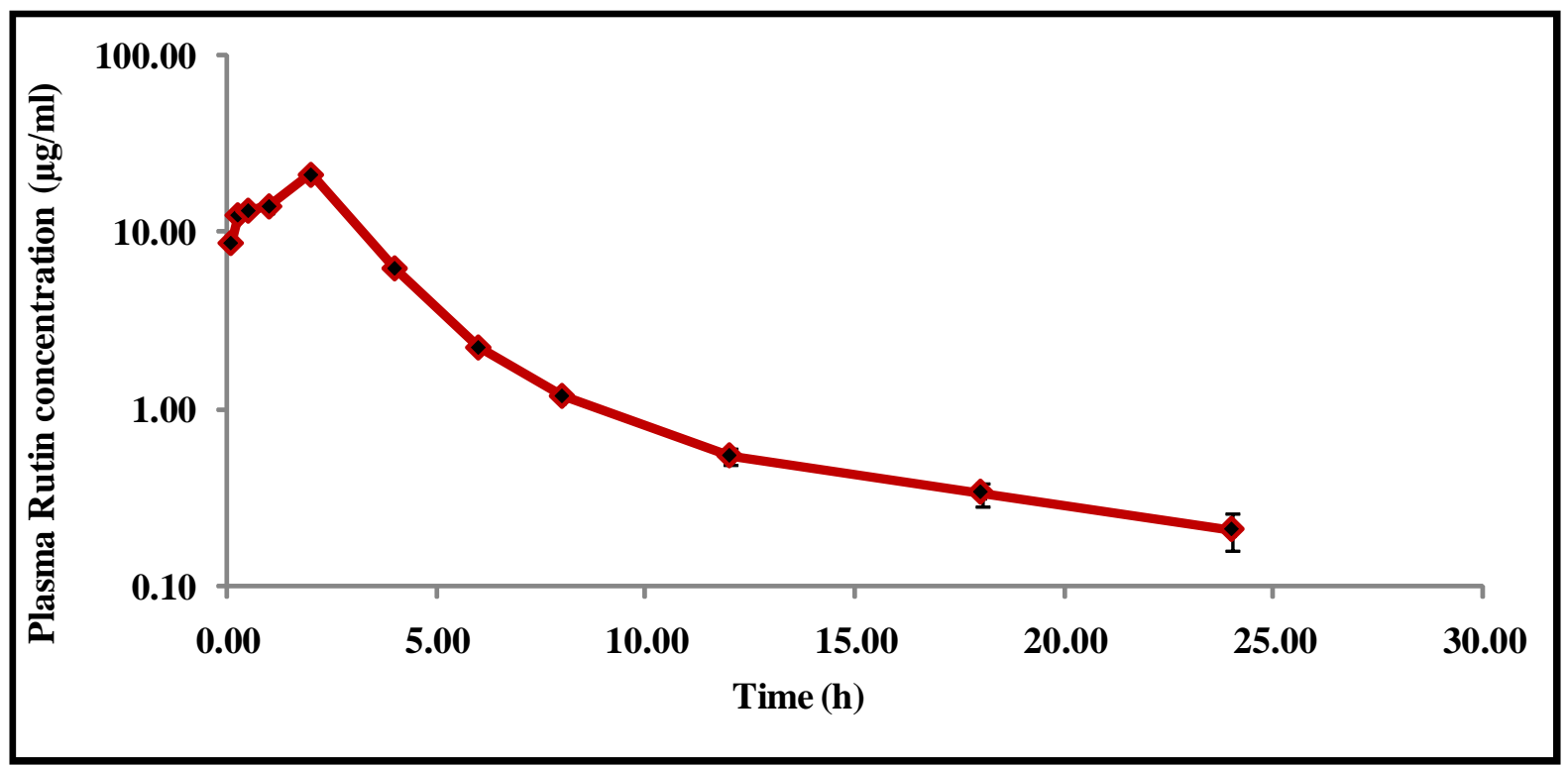

Figure 3: Semi logarithmic plot of rutin concentration in plasma versus time following single dose intramuscular administration of rutin $(100 \mathrm{mg} / \mathrm{kg})$ in rats. Each point represents Mean \pm S.E.

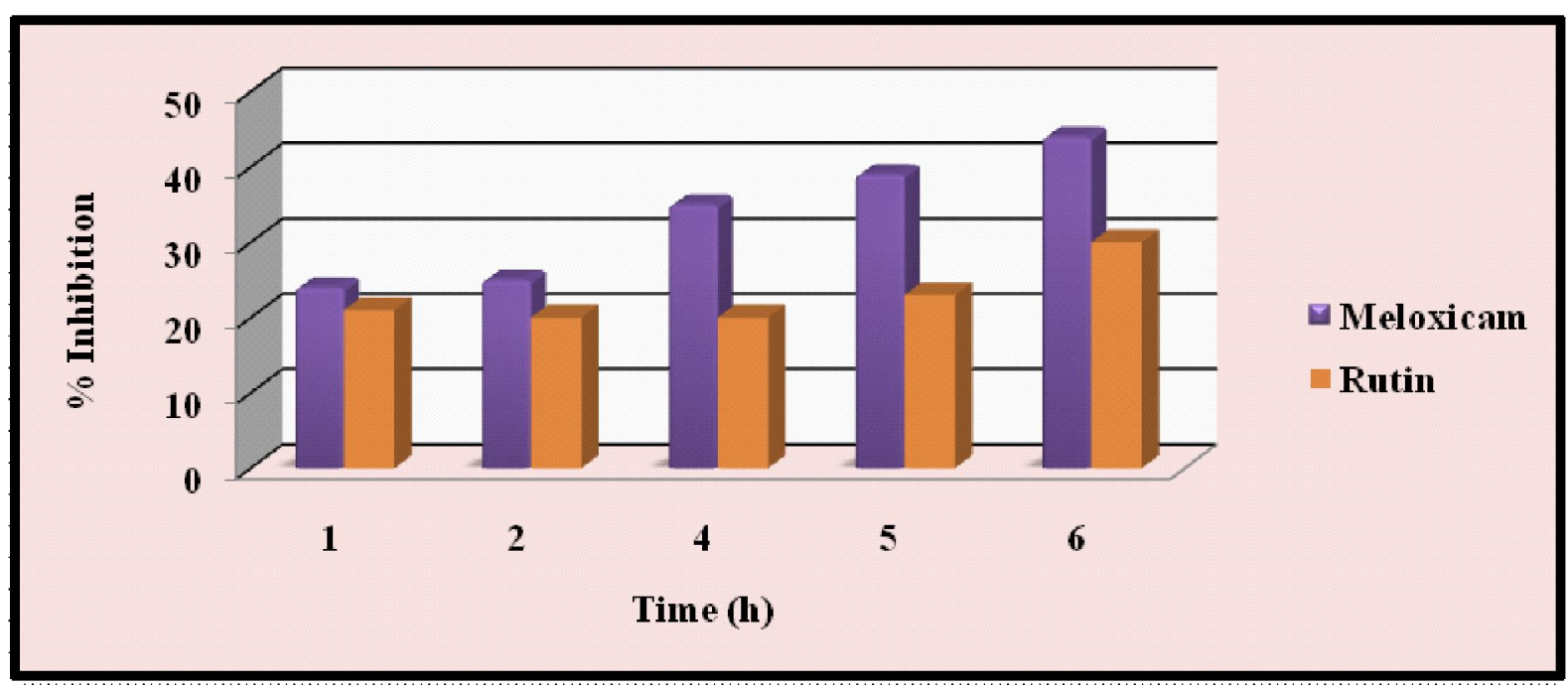

Figure 4: Per cent inhibition of inflammation by meloxicam and rutin at different time interval. Values are expressed as mean $\pm \operatorname{SE}(n=6)$.

\section{Discussion}

The pharmacokinetic and anti-inflammatory effect of rutin after intramuscular administration in rats has been determined and reported for the first time ever. The mean peak plasma drug concentration $\left(\mathrm{C}_{\max }\right)$ of $21.11 \pm 0.46 \mu \mathrm{g} / \mathrm{ml}$ was achieved at $2 \mathrm{~h}$. Contrary to the present findings, low $\mathrm{C}_{\max }$ of $1.55 \pm 0.19 \mu \mathrm{g} / \mathrm{ml}$, following oral administration of mulberry leaf aqueous extract (at a dose containing $34.86 \mathrm{mg} / \mathrm{kg}$ rutin) in rats (Yang et al., 2013) and $0.09 \mu \mathrm{g} / \mathrm{ml}$ after oral administration of rutin in healthy volunteers (Erlund et al., 2000). It is evident from previous investigations that when rutin as pure compound when administered orally, undergo deglycosylation by intracellular cytoplasmic $\beta$-glucosidase prior to absorption and subjected to passive diffusion of the resulting flavonoid aglycone (quercetin) through epithelial cells, which is supported by increased hydrophobicity. Moreover, rutin (quercetin-3-O-rutinoside) is deglycosylated by microfloral rhamnosidases and $\beta$-glucosidases present in the colon, and absorption of rhamnoglucosides is delayed and appears to be less efficient (Hsiu et al., 2002; Spencer et al., 1999). In addition, it is reported that parent form of rutin was not detected and absolute systemic bioavailability of rutin was essentially zero, following oral administration (Day et al., 1998; Jaganath et al., 2006).The concentration of rutin in rats achieved in the study, following intramuscular administration could be considered significant. The apparent volume of distribution $\left(\mathrm{Vd}_{\text {(area) }}\right)$ of rutin $16.34 \pm 2.32 \mathrm{1} / \mathrm{kg}$ in rats indicates extensive tissue uptake. This finding is supported as rutin and glucuronidated rutin were absorbed differently by the 
basolateral and apical membranes, and rutin showed differential permeability through the apical and basolateral sides (Zhang et al., 2013). Approximately, $33 \%$ of the rutin was metabolized to glucuronidated rutin, and the intracellular concentration of glucuronidated rutin was much lower than that of parent rutin. Contrary to the present findings, very low mean apparent volume of administration $\left(\mathrm{Vd}_{\text {(area) }}\right)$ of $0.021 / \mathrm{kg}$ (Zhang et al., 2016), $0.08 \pm$ $0.03 \mathrm{l} / \mathrm{kg}$ (Wang et al., 2010) and $1.58 \mathrm{l} / \mathrm{kg}$, following administration of Ginkgo biloba extracts (Tang et al., 2009) in rat and 2.62 1/kg in dog (Wu et al., 2012) has been reported, following intravenous injection of rutin. This indicates that pure form of rutin distributes extensively in the body. In support of above findings, total body clearance of $1.27 \pm 0.04 \mathrm{l} / \mathrm{h} / \mathrm{kg}$ with an estimated mean elimination half-life $\left(\mathrm{t}_{1 / 2 \beta}\right)$ of $9.11 \pm 1.50 \mathrm{~h}$ in rats were observed by us. Present observation of total body clearance is in agreement with little higher total body clearance of $2.64 \mathrm{l} / \mathrm{h} / \mathrm{kg}$ observed in dogs, following intravenous administration ( $\mathrm{Wu}$ et al., 2012). Contrary to the observation of the present study, very low total body clearance of $0.01 \mathrm{l} / \mathrm{h} / \mathrm{kg}$ (Chen et al., 2015), $0.32 \pm 0.01 \mathrm{l} / \mathrm{h} / \mathrm{kg}$ (Wang et al., 2010), $0.25 \pm 0.04 \mathrm{l} / \mathrm{h} / \mathrm{kg}$ (Zhang et al., 2016) and $0.66 \mathrm{l} / \mathrm{h} / \mathrm{kg}$ (Tang et al., 2009) in rats and $5.56 \pm 0.80 \mathrm{l} / \mathrm{h} / \mathrm{kg}$ (Liu et al., 2011) in rabbits were observed, following intravenous administration of rutin. Present findings are in agreement with elimination half-life $11.80 \pm$ $3.10 \mathrm{~h}$, following oral administration of rutin in humans (Yang et al., 2013 ) and $10.36 \pm 7.34 \mathrm{~h}$, following oral administration of mulberry leaf aqueous extract in rats (Graefe et al., 2001). However, following intravenous administration of rutin, short elimination half-life of $0.05 \pm 0.01 \mathrm{~h}$ (Zhang et al., 2016), $0.38 \pm 0.07 \mathrm{~h}$ (Chen et al., 2015) and $0.94 \pm 0.02 \mathrm{~h}$ (Wang et al., 2010) in rats and $2.13 \pm 0.59 \mathrm{~h}$ in rabbits were also reported. In addition, Wu et al. (2012) reported short elimination half-life of rutin $0.69 \mathrm{~h}$, following intravenous administration of Ginkgo biloba extracts in beagle dogs. In the present study, longer elimination half-life, high apparent volume of distribution and slow total body clearance of rutin, following intramuscular injection may be due to high tissue distribution owing to its high lipid solubility.

Carrageenan-induced inflammation is a biphasic phenomenon. It is evident that early phase (1-2 h) of the carrageenan-induced inflammatory model is mainly mediated by histamine, serotonin and increased synthesis of prostaglandins in the damaged tissue surroundings. The late phase is sustained by prostaglandin release and mediated by bradykinin, leukotrienes, polymorph nuclear cells and prostaglandins produced by tissue macrophages (Winter et al., 1962). In the present study, following intramuscular administration of rutin in inflammatory model significantly reduced the inflammation, caused by carrageenan in rats which could be comparable to effect produced by meloxicam up to $2 \mathrm{~h}$. However, the reduction in oedema in rutin treated animals was slightly lower as compared to meloxicam which might be due to low therapeutic effective meloxicam concentration than that of rutin as well as difference in pharmacokinetic profile of both agents. Moreover, it has been observed that rutin attenuated the inflammation in the liver by down-regulating the $\mathrm{CCl}_{4}$ induced activation of nuclear factor-kappa B (NF- $\mathrm{B}$ ), tumor necrosis factor- $\alpha$ (TNF- $\alpha)$ and cyclooxygenase (COX-2), following intraperitoneal injection and which may be attributed to the presence of a rutinoside moiety in position 3 of the $C$ ring (Domitrovic et al., 2012). In addition, rutin $(80 \mathrm{mg} / \mathrm{kg}$, intraperitoneal) was extremely effective in reducing edema, nodules and ankyloses than quercetin and hesperidin on adjuvant arthritis in rats (Guardia et al., 2001). Following oral administration of rutin at a dose rate of $100 \mathrm{mg} / \mathrm{kg}$ reduced rat paw swelling, starting $2 \mathrm{~h}$ after lambda-carrageenan injection (Selloum $e t$ al., 2003). Rutin isolated (1.5\% w/w) from extract of Cardispermum halicacabum leaves exhibited anti-inflammatory activity in chronic inflammatory model in rats (Venketash Babu and Krishnakumari, 2005). Rutin isolated from methanol extract of Ficus pumila significantly decreased the $\lambda$-carrageenan-induced mouse paw edema volume at the concentrations of 0.5 and $1 \mathrm{~g} / \mathrm{kg}$ (Liao et al., 2012). Carrageenan induced paw edema was significantly $(p<0.01)$ decreased at $3^{\text {rd }}$ and $4^{\text {th }} \mathrm{h}$ at the dose of $10 \mathrm{mg} / \mathrm{kg}$ of rutin in rats (Narwaria et al., 2015). Moreover, pharmacokinetic properties of rutin following intramuscular administration in rats support the anti-inflammatory activity of rutin in carrageenan-induced inflammation at paw.

\section{Conclusion}

In conclusion, after single dose intramuscular administration of rutin $(100 \mathrm{mg} / \mathrm{kg})$ in rat, therapeutic effective concentrations were maintained up to $24 \mathrm{~h}$ post drug administration. In rats, longer elimination half-life of parent form of rutin with good volume of distribution at a dose of $100 \mathrm{mg} / \mathrm{kg}$, intramuscularly significantly decreased edema volume within $6 \mathrm{~h}$. Further, extensive study is required to resolve the exact mechanism of action of the rutin.

\section{Acknowledgements}

The authors are highly thankful to Dean, College of Veterinary Science and A. H., Navsari, Gujarat, India for providing funds, and animal facilities to undertake the research work.

\section{Conflict of interest}

The authors declare that no conflict of interest exists in the course of conducting this research. All authors had final decision regarding the manuscript and the decision to submit the findings for publication.

\section{References}

Azevedo, M. I.; Pereira, A.F.; Nogueira, R.B.; Rolim, F.E.; Brito, G.A.C.; Wong, D.V.T., Lima-Junior, R.C.P.; Ribeiro, R.A. and Vale, M.L. (2013). The antioxidant effects of the flavonoids, rutin and quercetin inhibit oxaliplatin-induced chronic painful peripheral neuropathy. Molecular Pain, 9:53.

Baggot, J. D. (1977). Principles of drug disposition in domestic animals. The basis of veterinary clinical pharmacology. 1st Ed., W.B. Saunders Co., Philadelphia, U.S.A., pp:144-189.

Bhadarka, D.H.; Patel, U.D.; Ahmed, R., Patel , H.B.; Modi, C.M.; and Fefar, D.T. (2018). Biochemical and histologic evaluation following multiple dose administration of paracetamol alone and along with polyherbal extract mixture in rats. Ann. Phytomed., 7(2):114-123.

Chen, M.; Zhang, X.; Wang, H.; Lin, B.; Wang, S. and Hu, G. (2015). Determination of rutin in rat plasma by ultra performance liquid chromatography tandem mass spectrometry and application to pharmacokinetic study. Journal of Chromatographic Science, 53:519-525.

Day, A.J.; Dupont, M.S.; Ridley, S.; Rhodes, M.; Rhodes, M.J.C.; Morgan, M.R.A. and Williamson, G. (1998). Deglycosylation of flavonoid and isoflavonoid glycosides by human small intestine and liver $\beta$ glucosidase activity. FEBS Letter, 436:71-75.

Domitrovic, R.; Jakovac, H.; Marchesi, V.; Vladimir-Knezevic, S.; Cvijanovic, O.; Tadic, Z.; Romic, Z. and Rahelic, D. (2012). Differential hepatoprotective mechanisms of rutin and quercetin in $\mathrm{CCl}_{4}$-intoxicated $\mathrm{BALB} / \mathrm{cN}$ mice. Acta Pharmacologica Sinica, 33(10):1260-1270. 
Erlund, I.; Kosonen,T.; Alfthan, G.; Maenpaa, J.; Perttunen, K.; Kenraali, J.; Parantainen, J. and Aro, A. (2000). Pharmacokinetics of quercetin from quercetin aglycone and rutin in healthy volunteers. European Journal of Clinical Pharmacology, 56:545-553.

Gibaldi, M. and Perrier, P. (1982). Non-compartmental analysis based on statistical moment theory. Pharmacokinetics. 2nd ed. MarcelDekker Inc., New York, pp:409-417.

Graefe, E.U.; Wittig, J.; Mueller, S.; Riethling, A.K.; Uehleke, B.; Drewelow, B.; Pforte, H.; Jacobasch, G.; Derendorf, H. and Veit, M. (2001). Pharmacokinetics and bioavailability of quercetin glycosides in humans. Journal of Clinical Pharmacology., 41(5):492-499.

Guardia, T.; Rotelli, A.E.; Juarez, A.O. and Pelzer, L.E. (2001). Antiinflammatory properties of plant flavonoids. Effects of rutin, quercetin and hesperidin on adjuvant arthritis in rat. Farmaco. 56(9):683-687.

Hsiu, S.L.; Huang, T.Y.; Hou, Y.C. and Chao, P.D.L. (2002). Comparison of metabolic pharmacokinetics of naringin and naringenin in rabbits. Life Science, 70:1481-1489.

Jaganath, I.B.; Mullen, C.; Edwards, C.A. and Crozier, A. (2006). The relative contribution of the small and large intestine to the absorption and metabolism of rutin in man. Free Radical Research, 40:10351046

Jayakumari, S.; Ravichandiran, V.; Nirmala, S.; Divya, P.; Malarkodi Velraj; Vijayalakshmi, A. and Arthanareswar (2012). Anti-inflammatory activity of flavonoid fraction of Pisonia grandis R.Br leaves. Ann. Phytomed., 1(1):99-104.

Khan, M.; Kumar, S.; Sastry, J.L.N.; Gupta,A. and Ahmad, S. (2015). Analgesic and anti-inflammatory potential of three new topical polyherbal formulations in wistar rats. Ann. Phytomed., 4(1):90-93.

Kreft, S.; Knapp, M. and Kreft, I. (1997). Extraction of rutin from buckwhea (Fagopyrum esculentum Moench) seeds and determination by capillary electrophoresis. Journal of Agricultural and Food Chemistry, 47(11):4649-4652.

Liao, C.; Kao,C.; Peng, W.; Chang, Y.; Lai, S. and Ho,Y. (2012). Analgesic and anti-inflammatory activities of methanol extract of Ficus pumila L. in mice. Evidence-Based Complementary and Alternative Medicine, pp:34-41.

Liu,x.; Tang,D.; Wu, J. and Yin, X. (2011). Gradient HPLC-DAD determination and pharmacokinetic study of Ginkgo biloba extract in rabbits. Latin American Journal of Pharmacy, 30(3):507-513.

Narwaria, U.; Chauhan, P. and Sharma, M. (2015). Preparation and evaluation of anti-inflammatory activity of rutin phytosome. Current Research in Biological and Pharmaceutical Sciences, pp:8-10.

Nayanabhirama, U. (2016). Status on herbal drugs and their future properties. Ann. Phytomed., 5(1):1-3.

Selloum, L.; Bouriche, H.; Tigrine, C. and Boudoukha, C. (2003). Antiinflammatory effect of rutin on rat paw oedema, and on neutrophils chemotaxis and degranulation. Experimental and Toxicologic Pathology. 54(4):313-318.

Spencer, J.P.; Chowrimootoo, G.; Choudhury, R.; Debnam, E.S.; Srai, S.K. and Rice-Evans, C. (1999). The small intestine can both absorb and glucuronidate luminal flavonoids. FEBS Letter, 458:224-230.

Suebsasana, S.; Pongnaratorn, P.; Sattayasai, J.; Arkaravichien, T.; Tiamkao, S. and Aromdee, C. (2009). Analgesic, antipyretic, anti-inflammatory and toxic effects of andrographolide derivatives in experimental animals. Archives of Pharmacal Research, 32:1191-1200.

Tang, D.; Yin, X.; Zhang, Z.; Gao, Y.; Wei, Y.; Chen, Y. and Han, L. (2009). Comparative study on the pharmacokinetics of Ginkgo biloba extract between normal and diabetic rats by HPLC-DAD. Latin American Journal of Pharmacy., 28(3):400-408.

Thakur, K.; Navdeep, Anchal, Sunil Jaswal, S. and Bhatt, A. (2018). Evaluation of antimicrobial potential of root extract of Asparagus racemosus Willd. and bark extract of Juglans regia L. against pathogenic bacterial isolates. Ann. Phytomed., 7(2):64-69.

Vasudevan, M.; Gunnam, K.K. and Parle, M. (2007). Antinociceptive and antiinflammatory effects of Thespesia populnea bark extract. Journal of Ethnopharmacology, 109:264-270.

Venkateshbabu, K. and Krishnakumari, S. (2005). Anti-inflammatory and antioxidant compound, rutin in cardiospermum halicacabum leaves. Ancient Science of Life, 25(2):47-49.

Wang, S.Y.; Chai, J.Y.; Zhang, W.J.; Liu, X.; DU, Y.; Cheng, Z.Z.; Ying, X.X. and Kang, T.G. (2010). HPLC determination of five polyphenols in rat plasma after intravenous administration of hawthorn leaves extract and its application to pharmacokinetic study. Yakugaku Zasshi, 130(11): 1603-13.

Winter, C.A.; Risley, E.A. and Nuss, W. (1962). Carrageenan-induced oedema in hind paw of rats as an assay for antiinflammatory drugs. Proceedings of the Society for Experimental Biology and Medicine, 111:544-547.

Wu, J.; Xing, H.; Tang, D.; Gao, Y.; Yin, X.; Du, Q.; Jiang, X. and Yang, D. (2012). Simultaneous determination of nine flavonoids in beagle dog by HPLC with DAD and application of Ginkgo biloba Extracts on the pharmacokinetic. Acta Chromatographica. 24(4):627-642.

Yang, Z.; Cao, X.; Wei, Y.; Zhang, W.; Zhao, M. and Duan, J. (2013). Pharmacokinetic study of rutin and quercetin in rats after oral administration of total flavones of mulberry leaf extract. Revista Brasileira de Farmacognosia, 23:776-782.

Zhang, P.; Gou, Y.; Gao, X.; Bai, R.; Chen, W.; Sun, B.; Hu, F. and Zhao, W. (2016). The pharmacokinetic study of rutin in rat plasma based on an electrochemically reduced grapheme oxide modified sensor. Journal of Pharmaceutical and Biomedical Analysis, 6:80-86.

Zhang, X.; Song, J.; Shi, X.; Miao, S.; Li, Y. and Wen, A. (2013). Absorption and metabolism characteristics of rutin in Caco-2 cells. Scientific World Journal, pp:382-400.

Citation: Falguni D. Modi, Shailesh K. Bhavsar, Jatin H. Patel, Rasesh D. Varia, Lalit C. Modi, Megha Modi and Nitin Kale (2019). Pharmacokinetic profile of rutin after intramuscular administration in rats favours its in vivo antiinflammatory activity in carrageenan-induced rodent model of inflammation. Ann. Phytomed., 8(1):185-192. 